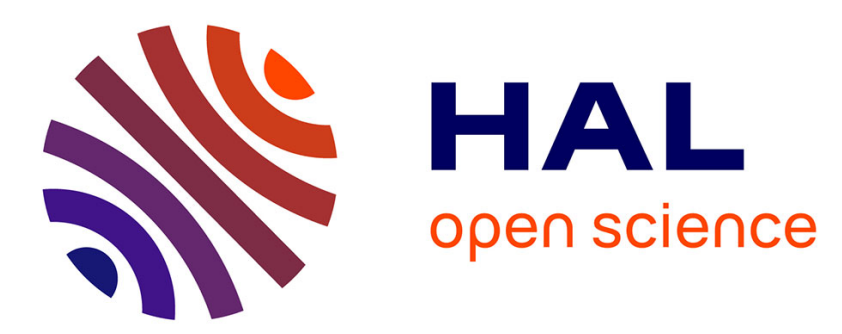

\title{
Exergy analysis of heat pumps for simultaneous heating and cooling
}

Paul Byrne, Redouane Ghoubali

\section{To cite this version:}

Paul Byrne, Redouane Ghoubali. Exergy analysis of heat pumps for simultaneous heating and cooling. Applied Thermal Engineering, 2019, 149, pp.414-424. 10.1016/j.applthermaleng.2018.12.069 . hal01990479

HAL Id: hal-01990479

\section{https://hal-univ-rennes1.archives-ouvertes.fr/hal-01990479}

Submitted on 23 Jan 2019

HAL is a multi-disciplinary open access archive for the deposit and dissemination of scientific research documents, whether they are published or not. The documents may come from teaching and research institutions in France or abroad, or from public or private research centers.
L'archive ouverte pluridisciplinaire HAL, est destinée au dépôt et à la diffusion de documents scientifiques de niveau recherche, publiés ou non, émanant des établissements d'enseignement et de recherche français ou étrangers, des laboratoires publics ou privés. 


\title{
Exergy analysis of heat pumps for simultaneous heating and cooling
}

\author{
Paul BYRNE*, Redouane GHOUBALI
}

Laboratoire LGCGM, Université de Rennes, France

IUT Génie Civil, 3 rue du Clos Courtel, BP 90422, 35704 Rennes Cedex 7, France

*paul.byrne@univ-rennes1.fr

Tel: +33223234297

Fax: +33223234051

\section{Abstract}

This article presents the evolution of a concept of air-source heat pump for simultaneous heating and cooling (HPS). A heat pump can simultaneously produce heating and cooling energies for collective residential buildings, hotels or highly-glazed office buildings. The heat pump prototypes operate under three main modes. (1) The heating mode produces hot water using heat available in the ambient air. (2) The cooling mode produces cold water and rejects heat to the ambient air. (3) The simultaneous mode produces hot water thanks to heat taken from the cold water, therefore becoming colder. During the simultaneous mode, two thermal energy amounts, for cooling and heating, are produced simultaneously. Therefore, it is interesting for the user that the heat pump operates in the simultaneous mode as much as possible. A winter operating sequence involving a heat exchanger for refrigerant subcooling enhances the performance of the machine. Two prototypes working with R407C and R290 (propane) were built consecutively and tested following European Standard EN 14511 in a climatic chamber. The experimental results show that the second prototype has a higher performance than the first one regarding exergy aspects thanks to not only the refrigerant choice but also to a better design of components.

Keywords: exergy, heat pump, heating, cooling, simultaneous, R407C, R290, propane 


\section{Introduction}

Improvements on a heat pump cycle are limited by the performance of the reverse Carnot cycle. The gap between the maximum performance and the real cycle performance can be evaluated using the concept of exergy. Exergy is a thermodynamic quantity defined as the maximum work available in a system referring to a specified environment temperature [1]. The concept of exergy appears interesting when applied to heat pumps for simultaneous heating and cooling. It enables to manipulate thermal energies produced at different temperatures converted in the same thermodynamic grandeur.

The introduction of this article details the exergy assessment method, reviews the scientific literature about heat pumps for simultaneous heating and cooling (HPS) and discusses the choice of refrigerants for this machine. Then, the experimental studies carried out in our laboratory on exergy assessment are presented. Two prototypes, P1 using R407C and P2 using R290, were tested in a climatic chamber in Pôle Cristal, Technical Research Centre for HVAC in Dinan France. The exergy comparisons are carried out under standard stationary conditions including an exergy destruction calculation for each component.

\subsection{Energy and exergy assessment}

Energy analysis is widely used in the engineering sector for system performance assessment, while exergy analysis determines the magnitude of energy losses in each component to reveal paths for potential improvements. It corresponds to a form of "quality" of an energy process [2]. No exergy is destroyed during a reversible process and a part of the exergy is destroyed during an irreversible one. For refrigeration cycles, the specific exergy of a fluid at any state is given by equation 1 [3], where $\mathrm{h}_{0}, \mathrm{~T}_{0}$ and $\mathrm{s}_{0}$ are respectively the reference values of specific enthalpy, temperature and specific entropy.

$e x=\left(h-h_{0}\right)-T_{0} \cdot\left(s-s_{0}\right)$

For heat pump cycles, exergy is used to evaluate the irreversibility degree of the processes. The objective of an optimization study is then to minimize the exergy destruction for each component of the heat pump. To define the exergy transfers throughout the different processes of the heat pump cycle, the Carnot efficiency is used following equation 2 , where $T_{0}$ is commonly taken as the ambient temperature [1] and $\bar{T}_{\text {so }}$ corresponds to the average source temperature (equation 3). The logarithmic mean temperature is commonly used. Using this form of the Carnot efficiency enables to evaluate exergy as the mechanical work ideally recoverable from an amount of thermal energy $\dot{Q}$ (equation 4).

$\eta_{\text {Carnot }}=\left|1-\frac{T_{0}}{\bar{T}_{\text {so }}}\right|$ 
$\bar{T}=\frac{T_{\text {in }}-T_{\text {out }}}{\ln \left(\frac{T_{\text {in }}}{T_{\text {out }}}\right)}$

$\dot{E x}=\dot{Q} \cdot \eta_{\text {Carnot }}$

The energy efficiency of the HPS is evaluated in terms of COP (equations 5, 6 and 7). Thermal energy is calculated using temperature and flow rate measurements during the tests. The electric power of the compressor and the auxiliaries (fan, pumps and control accessories) are taken into account.

$$
\begin{aligned}
& C O P_{\text {heating }}=\frac{\dot{Q}_{\text {heating }}}{\dot{W}_{\text {compressor }}+\dot{W}_{\text {auxiliaries }}} \\
& C O P_{\text {simultaneous }}=\frac{\dot{Q}_{\text {heating }}+\dot{Q}_{\text {cooling }}}{\dot{W}_{\text {compressor }}+\dot{W}_{\text {auxiliaries }}} \\
& C O P_{\text {cooling }}=\frac{\dot{Q}_{\text {cooling }}}{\dot{W}_{\text {compressor }}+\dot{W}_{\text {auxiliaries }}}
\end{aligned}
$$

Exergy efficiency is the ratio of the produced exergy rate over the exergy rate supplied to the system, which is the electric power consumed by the compressor (equations 8, 9 and 10). Electric energy and mechanical work are considered as pure forms of exergy. The power consumed by the auxiliaries is also taken into account in the exergy efficiency calculation.

$\eta_{\text {ex-heating }}=\frac{\dot{E} x_{\text {heating }}}{\dot{W}_{\text {compressor }}+\dot{W}_{\text {auxiliaries }}}$

$\eta_{\text {ex-simultaneous }}=\frac{\dot{E} x_{\text {heating }}+\dot{E} x_{\text {cooling }}}{\dot{W}_{\text {compressor }}+\dot{W}_{\text {auxiliaries }}}$

$\eta_{\text {ex }- \text { cooling }}=\frac{\dot{E x_{\text {cooling }}}}{\dot{W}_{\text {compressor }}+\dot{W}_{\text {auxiliaries }}}$

Improving the real heat pump cycle consists in minimizing the exergy destruction during the four processes of the thermodynamic cycle, especially during compression [3]. An exergy analysis enables to assess in each component the improvement that could be envisaged. The theoretical formulation for exergy destruction in each process is given by the following equations (equations 11 to 14). In the evaporator and the condenser, the destroyed exergy rate is the difference of exergy rate exchanged between the source and the refrigerant. For the expansion process (equation 13), the exergy destruction is negative; it becomes an exergy recovery. Pressures and temperatures in each point of the refrigeration cycle were measured during the experimental tests. Enthalpy and entropy were then calculated using EES software [4] that includes the Refprop database for thermodynamic properties of refrigerants.

$$
\begin{aligned}
& \dot{E x_{D-c p}}=\dot{W}-\dot{m} \cdot\left[\left(h_{\text {out }}-h_{\text {in }}\right)-T_{0} \cdot\left(s_{\text {out }}-s_{\text {in }}\right)\right] \\
& \dot{E x_{D-c d}}=\dot{m} \cdot\left[\left(h_{\text {in }}-h_{\text {out }}\right)-T_{0} \cdot\left(s_{\text {in }}-s_{\text {out }}\right)\right]-\dot{Q}_{\text {heating }} \cdot\left|1-\frac{T_{0}}{\bar{T}_{\text {so }}}\right| \\
& \dot{E x_{D-x p}}=\dot{m} \cdot\left[-T_{0} \cdot\left(s_{\text {in }}-s_{\text {out }}\right)\right] \\
& \dot{E x_{D-e v}}=\dot{Q}_{\text {cooling }} \cdot\left|1-\frac{T_{0}}{\bar{T}_{\text {so }}}\right|-\dot{m} \cdot\left[\left(h_{\text {out }}-h_{\text {in }}\right)-T_{0} \cdot\left(s_{\text {out }}-s_{\text {in }}\right)\right]
\end{aligned}
$$


Morosuk presents an interesting analysis of exergy split under avoidable and unavoidable exergy destruction [5]. A calculation compares cycles with unavoidable exergy destructions with the performance of the ideal heat pump cycle called "theoretical heat pump cycle" having an isentropic expansion process. Cycles with unavoidable exergy destructions are representative of technological limitations linked to manufacturing methods. The assumptions taken for cycles with unavoidable exergy destructions are the following: temperature pinches (minimum temperature difference between refrigerant and secondary fluid) at the condenser and the evaporator equal to $0.5 \mathrm{~K}$ and a compressor isentropic efficiency of $95 \%$. The rest of exergy destruction is considered as avoidable exergy destruction. The optimization of the heat pump cycle is carried out by minimizing this avoidable exergy destruction. The same article also splits the avoidable exergy destruction into an endogenous part, acting on the component itself and exogenous part, acting on other components. This method helps to detect the components on which improvements in efficiency would be the highest. The article concludes that the evaporator should be improved first and the compressor second, following avoidable exergy destruction results. The values assumed here as near future technological limits for compressor and heat exchanger seem arbitrary and far from the values obtained with our prototypes. Besides, another publication [6] indicates that the compressor is the component destroying the most exergy, followed by the condenser. Fazelpour and Morosuk [7] conclude that the exergy destruction is the highest in the expansion valve in the case of a transcritical $\mathrm{CO}_{2}$ cycle. Other exergy analyses were performed with experimental data in the aim of better comprehension of the behaviour of heat pumps [6], [8]-[10]. To summarize, it appears that the exergy destruction depends highly on temperature and pressure differences and indirectly on the sizing of the components. Indeed, correct operating conditions are closely linked to component sizing. The present article will only apply the basic exergy destruction assessment method to heat pumps for simultaneous heating and cooling.

\subsection{Characteristics of heat pumps for simultaneous heating and cooling}

The improvement of the thermal performance of building envelopes, the increasing consumptions related to a more intensive use of electrical appliances and the growth of the domestic hot water (DHW) demand in the residential sector are factors that often lead to simultaneous or slightly delayed heating and cooling demands. In this context, the recommendations of the International Energy Agency in the "technology roadmap" for 2050 [11] advocate the development of systems able to produce domestic hot water, heating and cooling at the same time. A heat pump for simultaneous heating and cooling (HPS) can be a solution to satisfy the fluctuating thermal demands in heating and cooling, simultaneous or not. A HPS is able to provide these two thermal capacities simultaneously. Therefore, some electric energy is saved compared to two mono-function devices that would have to produce in parallel heating and cooling or a reversible heat pump that would have to operate firstly in a heating mode and secondly in a cooling mode. The HPS applications are space heating, space cooling and domestic hot water production for buildings such as 
collective residences, hotels or glass-fronted office buildings in which the proportion of simultaneous demands in heating and cooling is high. This situation occurs mainly during mid-seasons (spring and autumn) for north-south oriented buildings in which rooms facing north demand heating and rooms facing south demand cooling. Another situation is encountered during summer when cooling and domestic hot water demands are simultaneous [12]. The food-processing industry can also use this type of technology for simultaneous refrigeration and hot water production.

Table 1 summarizes the studies found in the scientific literature on the subject of simultaneous multi-function heat pump systems. Heating or cooling in the application column means space heating or space cooling. The applications are numerous: air-conditioning, refrigeration, space heating, domestic hot water production for residential and office buildings, dairies... Lecrivain et al. [13] sized a HPS that produces hot water at $95{ }^{\circ} \mathrm{C}$ and chilled water at $0{ }^{\circ} \mathrm{C}$. The machine consists of two refrigerant circuits in cascade using R22 as a refrigerant in a low-temperature cycle and R114 in a high-temperature cycle. Over its total lifetime, this solution saved 36 tons of oil equivalent (toe, primary energy) compared to a natural gas boiler and a cooling unit. Ghosh et al. [14] quantified the economic benefits of a HPS in the industry. They found that with the electricity price of India, a heat pump with simultaneous production has a payback time less than 18 months. An air handling unit with simultaneous production of domestic hot water is presented by Gong et al. [15]. A prototype of $7 \mathrm{~kW}$ cooling capacity was achieved. The prototype was tested under different climatic conditions and the coefficient of performance achieved is equal to 6. Fatouh and Elgendy [16] developed a prototype of water to water heat pump using R134a as a refrigerant. The latter can operate in heating, cooling or simultaneous mode. The coefficient of performance in simultaneous mode is defined as the ratio of the sum of useful energy production over electrical power consumption. Other studies dealing with heat pumps for simultaneous heating and cooling using $\mathrm{CO}_{2}$ as a working fluid were carried out [17], [18].

All authors conclude to a performance improvement thanks to the simultaneous thermal productions. However, the systems are by essence more complex than mono-function devices. More components are to be bought, assembled and managed. The control strategy is automatically more complex. The HPS adapts the production to the needs of the building by rejecting or recovering excess heat on a free source such as ambient air, a geothermal well or a water loop. The free balancing source is also mentioned in table 1. In the theoretical work of Le Goff [19], the application and the balancing source are not clearly defined. This study presents a method to optimize a system depending on either an exergy, an economic or an ecologic performance factor. The balancing source is nearly exclusively ambient air. It is easy to find and handle. If no balancing source is used, it means that the system does not cover all the thermal demand in heating and cooling but only the lowest part. The remaining part of the demand is satisfied by a back-up heating or cooling system. 
Table 1: Summary of previous studies about simultaneous multi-function heat pump systems (*in « type of study $»$ column: Theo. $=$ Theoretical; Exp. $=$ Experimental; Sim. $=$ Simulation - N/A: not appropriate - N/C: not communicated)

\begin{tabular}{|c|c|c|c|c|c|c|}
\hline Main authors & Application & $\begin{array}{l}\text { Type of } \\
\text { study* }\end{array}$ & $\begin{array}{l}\text { Balancing } \\
\text { source }\end{array}$ & Fluid & $\begin{array}{c}\text { Nominal } \\
\text { capacity or } \\
\text { power }(\mathbf{k W})\end{array}$ & $\begin{array}{l}\text { Performance } \\
\text { indicators }\end{array}$ \\
\hline $\begin{array}{c}\text { Agrawal, } 2011 \\
{[21]}\end{array}$ & Heating, cooling & Exp. & Air & R744 & 2.5 (electric) & $\begin{array}{c}\text { Maximum system } \\
\mathrm{COP}=4.1\end{array}$ \\
\hline Amin, 2015 [31] & Desalination & Exp. & Solar & $\mathrm{R} 134 \mathrm{a}$ & $\mathrm{N} / \mathrm{C}$ & Average $\mathrm{COP}=8$ \\
\hline Attia, 2010 [32] & Desalination & Theo. & N/A & R22 & N/A & $\begin{array}{l}\text { Maximum COP } \\
\text { around } 11 \\
\end{array}$ \\
\hline $\begin{array}{c}\text { Bouttefroy, } 1990 \\
\text { [25] }\end{array}$ & Heating, cooling & Exp. & $\begin{array}{l}\text { No balancing } \\
\text { source }\end{array}$ & $\begin{array}{c}\text { R22 } \\
\text { R114 } \\
\text { cascade }\end{array}$ & 400 (electric) & $\begin{array}{c}\text { Average COP }= \\
4.29\end{array}$ \\
\hline Byrne, 2009 [33] & Heating, cooling & Sim. & Air & $\begin{array}{l}\text { R407C, } \\
\text { R744 }\end{array}$ & 15 (heating) & $\begin{array}{c}\text { Carnot COP, } \\
\text { COP, exergy } \\
\text { efficiency }\end{array}$ \\
\hline $\begin{array}{c}\text { Byrne, } 2011 \\
{[22],[23]}\end{array}$ & Heating, cooling & Exp. & Air & $\mathrm{R} 407 \mathrm{C}$ & 15 (heating) & $\begin{array}{c}\mathrm{COP}=6.52 \\
\left(\mathrm{Tev}=0.4^{\circ} \mathrm{C} ;\right. \\
\left.\mathrm{Tcd}=50.6^{\circ} \mathrm{C}\right)\end{array}$ \\
\hline Byrne, 2012 [34] & $\begin{array}{c}\text { Heating, cooling, } \\
\text { DHW }\end{array}$ & Sim. & Air & $\mathrm{R} 407 \mathrm{C}$ & 10 (heating) & $\begin{array}{c}\text { Annual maximum } \\
\mathrm{COP}=5.33\end{array}$ \\
\hline $\begin{array}{c}\text { Fatouh, } 2011 \\
{[16]}\end{array}$ & $\begin{array}{c}\text { Space cooling, } \\
\text { DHW }\end{array}$ & Exp. & $\begin{array}{c}\text { No balancing } \\
\text { source }\end{array}$ & $\mathrm{R} 134 \mathrm{a}$ & 1 to 2 (electric) & $\begin{array}{c}\text { Maximum actual } \\
\text { COP }=4.9\end{array}$ \\
\hline Ghosh, 1987 [14] & $\begin{array}{l}\text { Dairy, brewery, } \\
\text { food processing }\end{array}$ & Sim. & $\begin{array}{c}\text { No balancing } \\
\text { source }\end{array}$ & $\mathrm{R} 12$ & $\begin{array}{l}100 \text { to } 350 \\
\text { (heating) }\end{array}$ & $\begin{array}{l}\text { Payback period, } \\
\text { less than } 1.5 \text { year }\end{array}$ \\
\hline $\begin{array}{c}\text { Ghoubali, } 2014 \\
\text { [12] }\end{array}$ & $\begin{array}{c}\text { Heating, cooling, } \\
\text { DHW }\end{array}$ & Sim. & Air & $\begin{array}{l}\text { R407C, } \\
\text { R290, } \\
\text { R1234yf } \\
\end{array}$ & 20 (heating) & $\begin{array}{c}\text { SCOP from } 2.28 \\
\text { to } 3.21\end{array}$ \\
\hline Gong, 2008 [15] & $\begin{array}{c}\text { Cooling, heating, } \\
\text { DHW }\end{array}$ & Exp. & & $\mathrm{R} 22$ & 2.6 (electric) & $\begin{array}{c}\text { Maximum COP }= \\
6.0\end{array}$ \\
\hline $\begin{array}{c}\text { Kang, } 2009[35] \\
\text { Joo, } 2011[36] \\
\text { Jung, 2014 [37] }\end{array}$ & Cooling, heating & & Air & R410A & 8 (cooling) & $\begin{array}{c}\text { Maximum } \mathrm{COP}= \\
7.69\end{array}$ \\
\hline $\begin{array}{c}\text { Lécrivain, } 1982 \\
\text { [13] }\end{array}$ & Dairy & & Air & $\begin{array}{c}\text { R22 } \\
\text { R114 } \\
\text { cascade }\end{array}$ & $\begin{array}{c}36\left(1^{\text {st }} \text { stage }\right) \\
38\left(2^{\text {nd }} \text { stage }\right) \\
\text { Electric power }\end{array}$ & $\mathrm{COP}=2.8$ \\
\hline $\begin{array}{c}\text { Le Goff, } 1999 \\
\text { [19] }\end{array}$ & Heating, cooling & Theo. & Environment & N/A & N/A & $\begin{array}{c}\text { Exergy, economic, } \\
\text { ecologic }\end{array}$ \\
\hline Liu, 2014 [38] & $\begin{array}{l}\text { Heating, cooling, } \\
\text { DHW }\end{array}$ & Exp. & Air, gray water & $\mathrm{N} / \mathrm{C}$ & 6 (heating) & $\begin{array}{c}\text { Heating and DHW } \\
\text { COP from } 5.8 \text { to } \\
4.8\end{array}$ \\
\hline $\begin{array}{c}\text { Naveteur, } 2007 \\
{[26]}\end{array}$ & Heating, cooling & Exp. & Ground & $\mathrm{N} / \mathrm{C}$ & $\begin{array}{l}600 \text { (heating, } \\
\text { cooling) }\end{array}$ & $\begin{array}{c}\text { Average COP }= \\
3.8 \\
\end{array}$ \\
\hline Sarkar, 2004 [17] & Heating, cooling & Sim. & $\begin{array}{l}\text { No balancing } \\
\text { source }\end{array}$ & R744 & $\mathrm{N} / \mathrm{C}$ & $\begin{array}{c}\text { COP }=8.08 \\
\text { Exergy efficiency } \\
=46.3 \%\end{array}$ \\
\hline Sarkar,2006 [18] & Heating, cooling & Sim. & $\begin{array}{c}\text { No balancing } \\
\text { source }\end{array}$ & R744 & 4 (cooling) & $\begin{array}{c}\text { Maximum system } \\
\text { COP }=4.01\end{array}$ \\
\hline Stene, 2005 [24] & Heating, DHW & $\begin{array}{l}\text { Exp. } \\
\text { Sim. }\end{array}$ & Brine & R744 & 6.5 (heating) & $\begin{array}{l}\text { Exp. COP }=3.9 ; \\
\text { Sim. COP }=4.3\end{array}$ \\
\hline White, 1997 [27] & $\begin{array}{c}\text { Refrigeration, } \\
\text { DHW }\end{array}$ & Exp. & $\begin{array}{c}\text { No balancing } \\
\text { source }\end{array}$ & R744 & $\begin{array}{l}400 \text { (cooling) } \\
600 \text { (heating) }\end{array}$ & Heating $\mathrm{COP}>3$ \\
\hline
\end{tabular}

In general, the laboratory experimental works usually focus on low capacity heat pumps ([15]-[18], [20]-[24]) whereas the plants operated in real conditions are much more powerful [14], [25]-[27]. Chua et al. [28] reviews the advances in heat pump systems and points out the application of district heating and cooling [29], [30]. However, these systems do not carry out simultaneous but alternative heating and cooling. Nevertheless, carrying out heating and cooling more efficiently is seen as an advance for heat pump systems. All these heat pumps are interesting solutions to 
heat, cool and even produce domestic hot water. They work using different operating modes in order to adapt the thermal productions of the machine to the thermal demands of a building or a process. In addition, the control strategy appears to be a key point to optimize the heat pump performance and to adapt thermal productions to the needs of the users and to the nature of the building.

\subsection{Refrigerants}

Currently, policy actions for the environment have imposed new restrictions on synthetic fluids. In the next revision of regulations on refrigerants, HFC use will be most likely restricted (or subject to taxation) especially in Europe [39]. However, the implementation of a protocol banning HFC remains hypothetical in a medium term horizon [40]. In this context, the use of natural refrigerants such as carbon dioxide $\left(\mathrm{CO}_{2}, \mathrm{R} 744\right)$, ammonia $\left(\mathrm{NH}_{3}, \mathrm{R} 717\right)$ and hydrocarbons (such as propane, $\mathrm{C}_{3} \mathrm{H}_{8}, \mathrm{R} 290$ ) is now considered as a promising alternative due to their low impact on the environment. Widely used in the first refrigeration systems, natural refrigerants were replaced in the 1930s by synthetic fluids. In recent years, a growing interest to return to these fluids has appeared among the research community. Figure 1 shows the performance of the fluids with low GWP based on the standard of comparison of a thermodynamic cycle of $20 \mathrm{~kW}$ heating capacity with an evaporation temperature of $0{ }^{\circ} \mathrm{C}$ and a condensing temperature of $40{ }^{\circ} \mathrm{C}$ (superheating and subcooling degrees of $0 \mathrm{~K}$ ). The best performance is obtained with ammonia. However, carbon dioxide has the compressor with smaller swept volume. Unlike developments of $\mathrm{CO}_{2}$ or ammonia systems that require the use of new technologies (often very costly), hydrocarbons offer an attractive alternative. Propane (R290) can be implemented in standard technologies. This fluid delivers an almost identical power as R22 with the same performance. The only relevant limitation for the use of hydrocarbons is flammability. This risk can be managed by reduced refrigerant charge, cautious confinement, namely by using ATEX components and leakage detection when the equipment is intended to be used in explosive atmospheres such as refineries or grain silos [41]. 


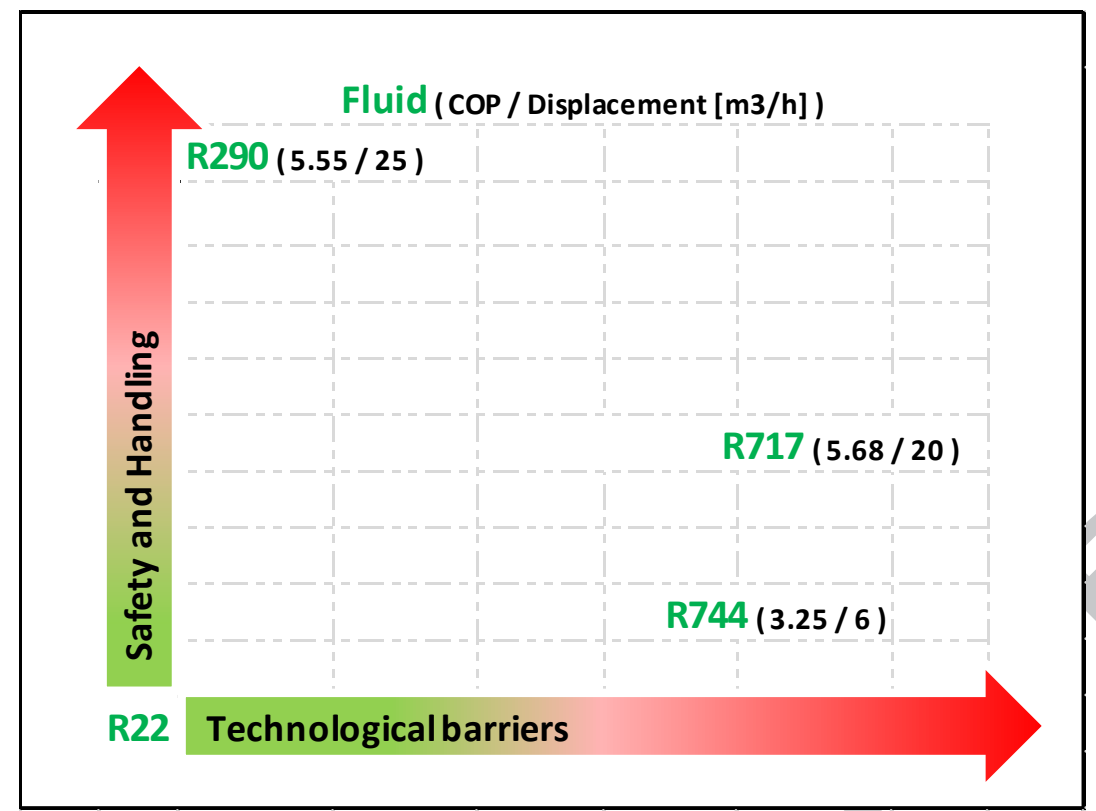

Figure 1: Fluid performance, compressor displacement and relative levels in terms of technological barriers and safety issues

In a previous publication [42], the performance of thermodynamic cycles of some refrigerants was compared by simulation for an air-source heat pump working in two applications: water heating at $35^{\circ} \mathrm{C}$ for space heating and domestic hot water production at $65^{\circ} \mathrm{C}$. The simulations were run using the cycle analysis tool of Coolpack [43], software working with Engineering Equation Solver [4]. CoolPack is a collection of simulation programs that can be used for designing, dimensioning, analysing and optimizing refrigeration systems.

The polyvalent fluorinated fluids such as CFC12, HCFC22 and HFC134a are less and less efficient as they lose atoms of chlorine and gain atoms of hydrogen instead. Among these, R407C takes advantage of the $5 \mathrm{~K}$-higher evaporating temperature due to the temperature glide during evaporation. However, it does not outperform other refrigerants in DHW production. Hydrocarbons show results equivalent to fluorinated fluids. All refrigerants show similar coefficients of performance except carbon dioxide that is better in DHW production than in space heating.

Mainly because of the simplicity to find components, the first prototype was designed with HFC R407C. To approach refrigeration with a natural fluid, the second prototype was implemented with propane. The COP and exergy efficiency of refrigeration cycles can be easily evaluated using Coolpack software for R407C and propane. The following assumptions can be made:

- temperature difference for water is equal to $5 \mathrm{~K}$,

- temperature difference for air is equal to $8 \mathrm{~K}$,

- temperature pinch is equal to $5 \mathrm{~K}$,

- $\quad$ isentropic efficiency is equal to 0.7 ,

- refrigerant subcooling and superheat are equal to $0 \mathrm{~K}$, 
- no pressure drops in the heat exchangers,

- no compressor heat loss,

- $\quad$ ambient temperature in the simultaneous mode is $11,3{ }^{\circ} \mathrm{C}$ (average ambient air temperature in the city of Rennes),

- temperature regimes in the three modes are the ones compared in the following study.

Table 2 presents simulation results of the thermodynamic cycle COP and of the exergy efficiency for the three operating modes and for the temperature regimes that are tested experimentally in standard EN 14511 [44]. This set of simulations shows that the refrigerant substitution does not have much influence on the performance factors in the heating and cooling modes. However, in the simultaneous mode, the temperature glide of R407C highly influences the coefficient of performance and the exergy efficiency consequently. Indeed, because of the glide, the evaporating temperature is higher and the COP increases. The condensing temperature stays the same because the high temperature is the set point temperature, e.g. the outlet temperature. In the cooling mode as in the simultaneous mode, the evaporating temperature is higher with $\mathrm{R} 407 \mathrm{C}$, but conversely, the condensing temperature is also higher. The high temperature of the temperature regime corresponds to the air inlet temperature in the cooling mode. Therefore, the condensing temperature increases as much as the evaporating temperature and the COPs of R407C and R290 thermodynamic cycles remain close. This aspect will have to be taken into account in the performance comparison between prototypes P1 (R407C) and P2 (R290).

Table 2: Simulation of the thermodynamic cycle COP and exergy efficiency with R407C and R290 under standard EN 14511 operating conditions

\begin{tabular}{|l|c|c|c|c|c|c|c|c|c|c|}
\hline \multirow{2}{*}{ Mode } & \multicolumn{9}{c|}{ Simultaneous mode } & \multicolumn{4}{c|}{ Heating mode } & \multicolumn{3}{c|}{ Cooling mode } \\
\cline { 2 - 13 } & $\mathbf{7 / 3 5}$ & $\mathbf{7 / 4 5}$ & $\mathbf{7 / 5 5}$ & $\mathbf{7 / 3 5}$ & $\mathbf{2 / 3 5}$ & $\mathbf{7 / 4 5}$ & $\mathbf{2 / 4 5}$ & $\mathbf{7 / 2 5}$ & $\mathbf{7 / 3 0}$ & $\mathbf{7 / 3 5}$ \\
\hline COP cycle R407C & 10.52 & 7.66 & 5.79 & 4.60 & 4.08 & 3.63 & 3.30 & 5.15 & 4.27 & 3.59 \\
\hline COP cycle R290 & 9.08 & 6.90 & 5.40 & 4.65 & 4.12 & 3.70 & 3.35 & 5.20 & 4.33 & 3.66 \\
\hline Discrepancy on COP & $13.7 \%$ & $10.0 \%$ & $6.7 \%$ & $-1.1 \%$ & $-0.8 \%$ & $-1.9 \%$ & $-1.6 \%$ & $-1.0 \%$ & $-1.4 \%$ & $-1.9 \%$ \\
\hline$\eta_{\text {ex }}$ R407C & 0.433 & 0.451 & 0.446 & 0.383 & 0.407 & 0.408 & 0.422 & 0.287 & 0.312 & 0.325 \\
\hline$\eta_{\text {ex }}$ R290 & 0.378 & 0.411 & 0.421 & 0.387 & 0.410 & 0.416 & 0.429 & 0.290 & 0.318 & 0.334 \\
\hline Discrepancy on $\eta_{\mathrm{ex}}$ & $12.7 \%$ & $9.0 \%$ & $5.8 \%$ & $-1.1 \%$ & $-0.8 \%$ & $-1.9 \%$ & $-1.6 \%$ & $-1.0 \%$ & $-1.7 \%$ & $-2.7 \%$ \\
\hline
\end{tabular}

The study presents the exergy analysis of experimental results obtained with the two prototypes tested under standard EN 14511 [44] conditions obtained in a climatic chamber. One specificity of these research results is that they compare three operating modes for the same machine that uses the same compressor and for two different heat pumps for simultaneous heating and cooling of similar power. 


\section{Concept of the HPS}

A reversible heat pump can provide alternatively either only cooling or only heating. The alternation is carried out by switching a 4-way reversing valve. Conversely, the HPS is characterized by its ability to produce simultaneously a heating capacity with a useful condenser and a cooling capacity with a useful evaporator. The system needs an additional heat exchanger with a balancing source such as ambient air or the ground to adapt the produced heating and cooling energy to the thermal demand. It also necessitates valves on the refrigeration circuit to supply the refrigerant flow to the heat exchangers involved in the different operating modes. The HPS operates in three basic modes: simultaneous, heating and cooling modes.

The two architectures of prototypes were designed for very specific reasons. Firstly, they both use ambient air as a balancing source because it is the cheapest. Secondly, they carry out defrosting in a very special manner. The cold water tank is used as storage tank during winter. Heat is recovered by subcooling the refrigerant in a heating mode and is subsequently used as a heat source for evaporation in a simultaneous mode. In prototype P1 operation, some of the vapour formed at the evaporator flows to the possibly frosted air evaporator to condense and defrost it. The refrigerant liquid returns to the water evaporator by gravity. This two-phase thermosiphon defrosting technique imposed the refrigeration circuit of the first prototype. The second prototype architecture has another goal: being more simple and efficient in order to be closer to a machine ready to the market. A sort of reversed cycle defrosting replaces the twophase thermosiphon defrosting. However, the defrosting energy is still drawn from the cold water tank that is unused during winter.

\subsection{P1: R407C prototype}

\subsubsection{General specifications}

An experimental HPS prototype using R407C as a refrigerant was first developed [22], [23] (Figure 2). It has an Emerson Copeland ZB38KCE compressor providing a nominal heating capacity of $15 \mathrm{~kW}$. The water evaporator and the water condenser are connected to two 300-litre tanks, respectively cold and hot water tanks. No DHW tank was installed in this first study. Condensation (marked HP, high pressure circuit) and evaporation (marked LP, low pressure circuit) on air are carried out on the same balancing air heat exchanger alternatively. Three modes can be operated with this machine:

- The simultaneous mode produces hot and chilled water using the water condenser and the water evaporator (electronic valves Evr1 and Evr3 are open).

- The heating mode produces hot water using the water condenser, the air evaporator (electronic valves Evr2 and Evr3 are open) and the subcooler to store the subcooling energy in the cold water tank. 
- The cooling mode only produces cold water using the water evaporator and the air condenser (electronic valves Evr1 and Evr4 are open).

EvrLP and EvrHP are two electronic valves that control the high pressure in the liquid receiver. When EvrHP opens, high pressure refrigerant from the compressor discharge line enters the bottle and increases the high pressure of the whole circuit. When EvrLP opens, the receiver is in connection with the low pressure part of the circuit and the high pressure decreases. This control management proved to be quite efficient even if some energy was lost by the pressure increase with hot gas.

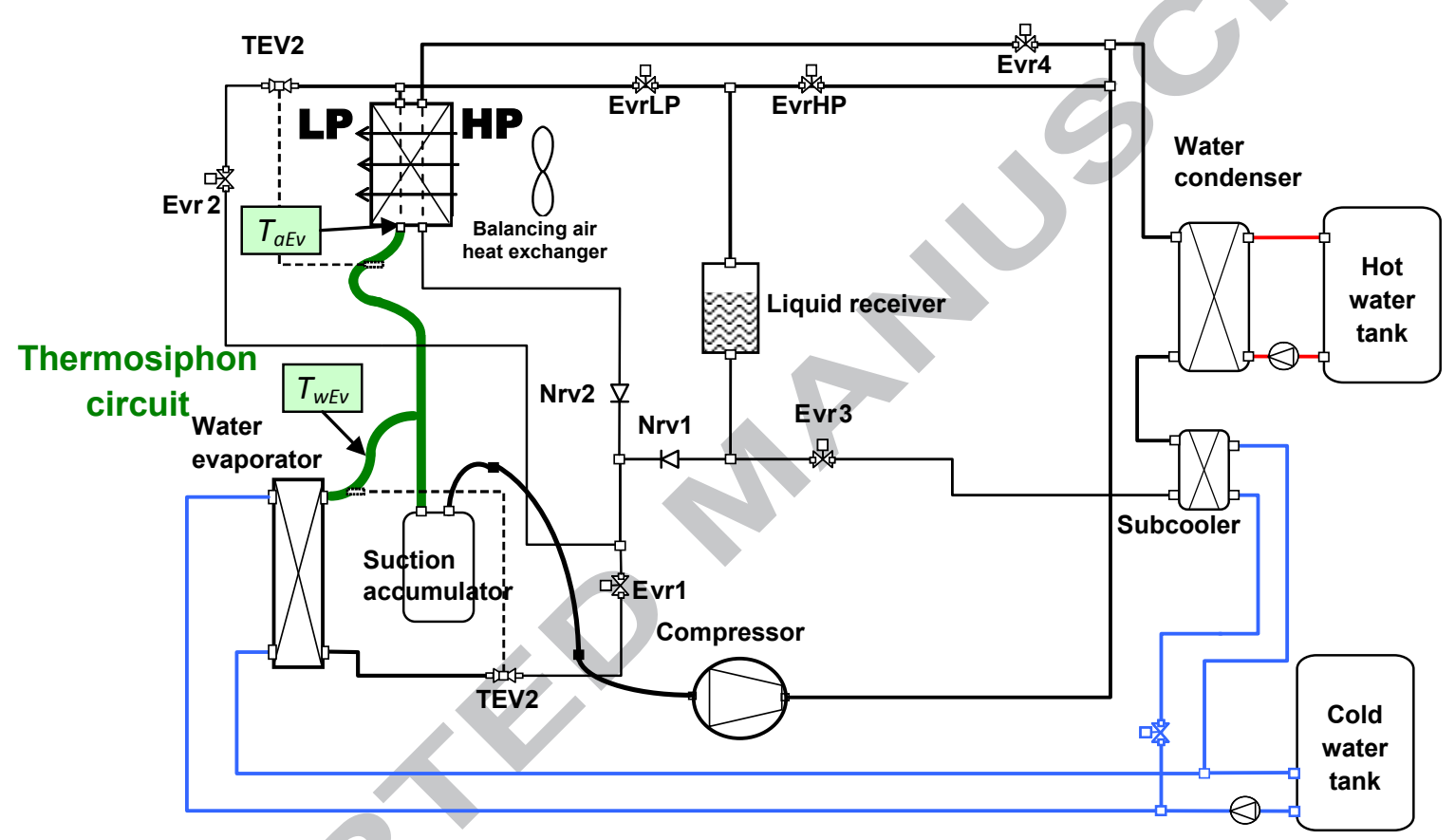

Figure 2: Scheme of the R407C HPS prototype

\subsubsection{Classic winter sequence}

During winter, the operation alternates between heating and simultaneous modes. The cold water tank is used as a short-time heat storage. The sequence begins by the heating mode involving the water condenser, the air evaporator and the subcooler. The cold water tank is heated, from around 10 to $20^{\circ} \mathrm{C}$, by the energy recovered by the refrigerant subcooling process. Then the HPS switches to the simultaneous mode and uses the energy stored in the cold water tank as a cold source for the water evaporator. The cold water tank temperature decreases progressively from 20 back to 10

${ }^{\circ} \mathrm{C}$. The controller switches again to the heating mode and this alternating process continues until the demand is satisfied.

In the simultaneous mode, the evaporating temperature is higher than in the heating mode as the cold water is hotter than ambient air. Therefore, using the simultaneous mode for a certain time during the winter sequence enables to produce hot water continuously with an improved average system performance compared to standard air-source heat 
pumps. Besides, in the simultaneous mode, the air evaporator is not used for evaporation, so it is free for a defrosting phase.

\subsubsection{Winter sequence with defrosting}

In the heating mode, under cold outside air temperatures and high humidity ratios, the fins of the air evaporator may get frosted. Before the frost thickness becomes critical, the cold tank of the HPS system was heated up to $20^{\circ} \mathrm{C}$ and the simultaneous mode was engaged by the controller. The frost thickness was observed with eye to remain limited with this $20^{\circ} \mathrm{C}$ operating threshold in the most severe frosting conditions. The lower cold tank temperature is a know-how that cannot be given in this article. The temperature is directly measured by the controller. In the simultaneous mode, the air coil is automatically defrosted by a two-phase thermosiphon formed between the two evaporators [23][22]. A supplementary flow of vapour comes out of the water evaporator and migrates towards the air evaporator where the temperature and the pressure are lower. The refrigerant exchanges latent heat with the frosted fins and condenses. It finally flows back to the water evaporator by gravity. The tube between the two evaporators must have a large diameter and a near-to-constant slope to let the refrigerant vapour flow up to the air evaporator while the condensed liquid flows back down to the water evaporator.

A major advantage of this sequence is to carry out defrosting without stopping the heat production. Frost thickness can thus be minimized and the mean overall heat transfer coefficient at the evaporator can be maximized. The average heat pump efficiency under frosting conditions is improved compared to the performance of standard air-source heat pumps that use hot gas or reversed cycle defrosting methods [45], [46]. Simulations with and without the alternated winter sequence have shown a seasonal heating and cooling COP increase of $15 \%$, from 2.54 to 2.92 , for a R407C HPS installed in an office building in Rennes (France) [12].

Some additional tests have shown that the configuration of the thermosiphon circuit worked well under low frosting conditions but was not fully optimized to carry out defrosting under severe frosting conditions [47]. Too much liquid formed rapidly inside the tubes of the air evaporator, it had not enough time to go back down to the water evaporator and actually blocked the upward vapour flow. This problem does not affect further comparison results because the defrosting sequences are not taken into account, only established operating modes under controlled air and water temperatures in a climatic chamber. However, this problem has to be solved by more research in the future.

\subsection{P2: R290 prototype}

\subsubsection{General specifications}

The second prototype (Figure 3 ) benefits from the previous works and simplifies the HPS system with the mid-term objective of the industrialization of the machine [47]. The 6 operating modes are presented in Figure 4. 
- $\quad$ Simultaneous mode (space cooling and space heating), Figure 4a

- $\quad$ Simultaneous DHW mode (space cooling and DHW production), Figure $4 \mathrm{~b}$

- Heating mode (space heating only), Figure 4c

- $\quad$ DHW mode (with ambient air), Figure 4d

- Cooling mode (space cooling only), Figure 4e

- $\quad$ Defrosting mode (cooling mode with stopped fan), Figure 4f

\subsubsection{Particularities}

The three principal modes and the alternating winter sequence are retained. Two additional modes were provided for DHW production (Figure 4b and Figure 4d). Two condensers are connected in series and work only alternatively depending on the activated mode. A DHW production demand has the priority on a space heating demand. Because of the higher inertia of the building and its space heating distribution network than of the DHW network, the impact of a stop of heat production for space heating during the DHW production will not so much impact the indoor temperature and the thermal comfort inside the building. Conversely, not immediately satisfying the DHW demand would be a clear cause of discomfort. The balancing air heat exchanger operates either as a condenser or as an evaporator. The refrigerant flows in a way in a condenser mode and in the opposite way in an evaporator mode. The ATEX Bock compressor referenced HG34P/255-4S was installed on this machine and provides a nominal heating capacity of 12 $\mathrm{kW}$. The simplification relies in the abandon of the high pressure control system and the thermosiphon defrosting. It was shown that the high pressure control system was not necessary when a liquid receiver was used. The high pressure is now indirectly controlled by the thermostatic expansion valves. Besides, the defrosting operation is carried out in a dedicated defrosting mode corresponding to a cooling mode with evaporation using the water from the cold tank and condensation using ambient air but without activating the condenser fan (figure $4 \mathrm{f}$ ). The defrosting process stops the heat production. However, it does not need to draw on the heat stock like in the one of a reversible heat pump. The average COP improvement of this technique is around $30 \%$ for an operation during a defrosting sequence at an ambient air temperature of $2{ }^{\circ} \mathrm{C}$ and a hot water production temperature of $35^{\circ} \mathrm{C}$ [48] if compared to reversible heat pump. 


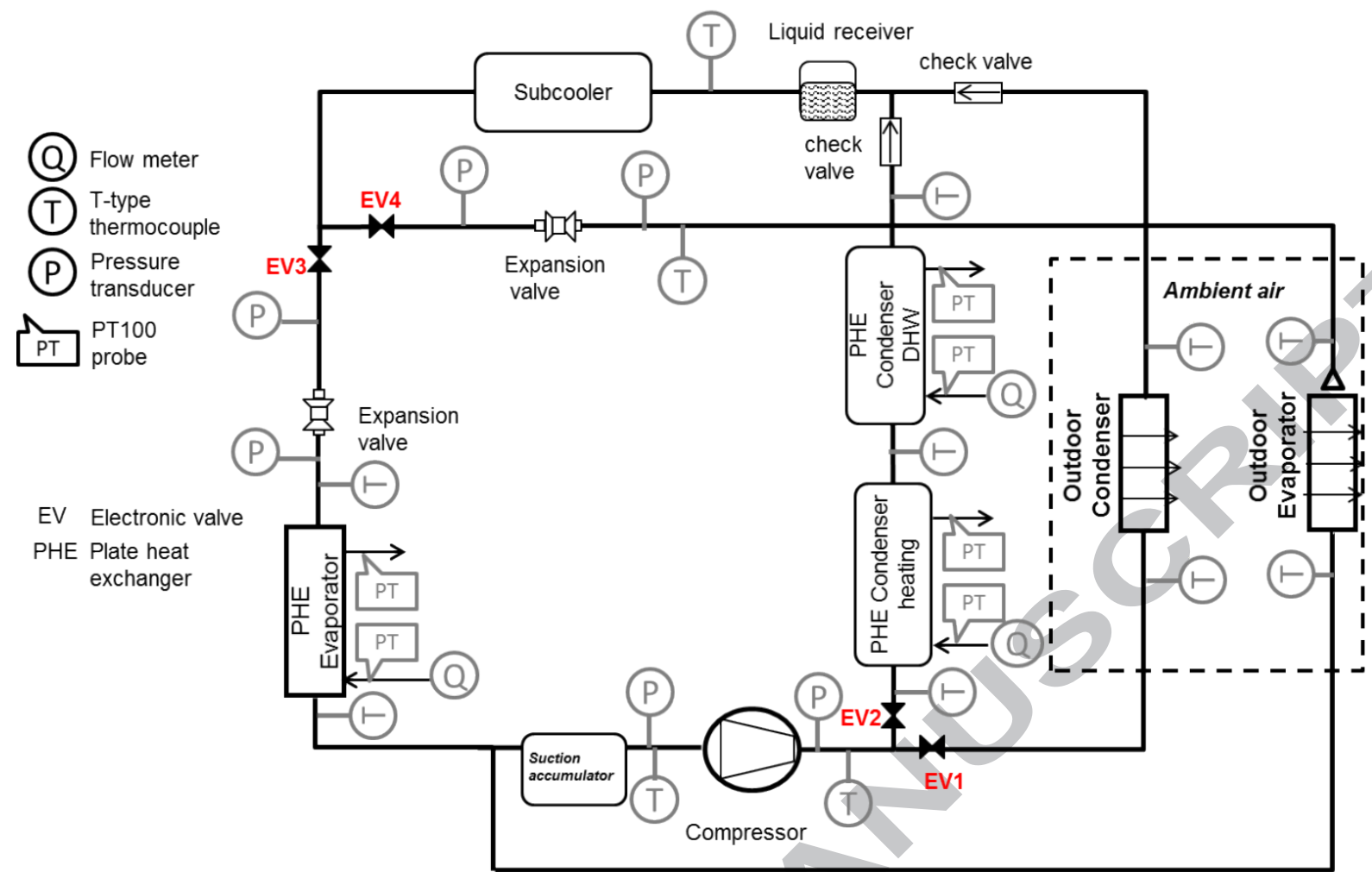

Figure 3: Schematic layout of the R290 HPS

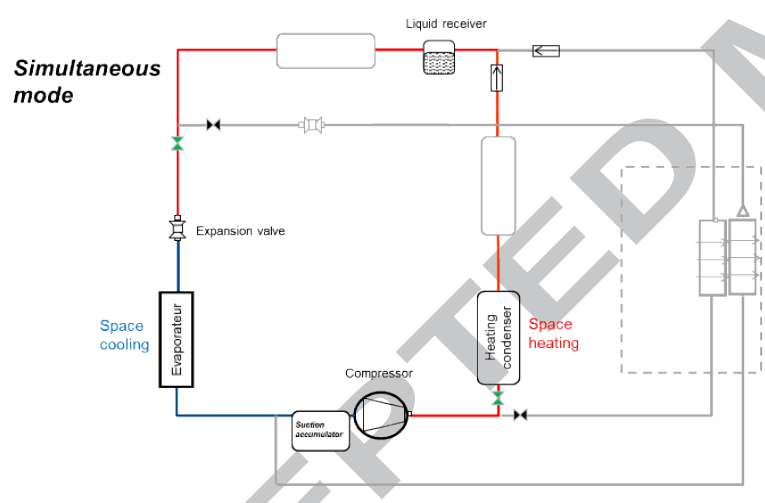

(a)

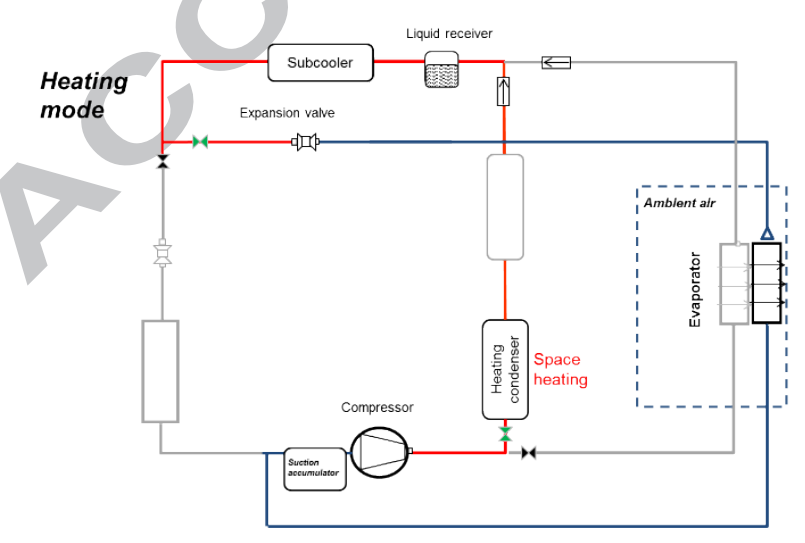

(c)

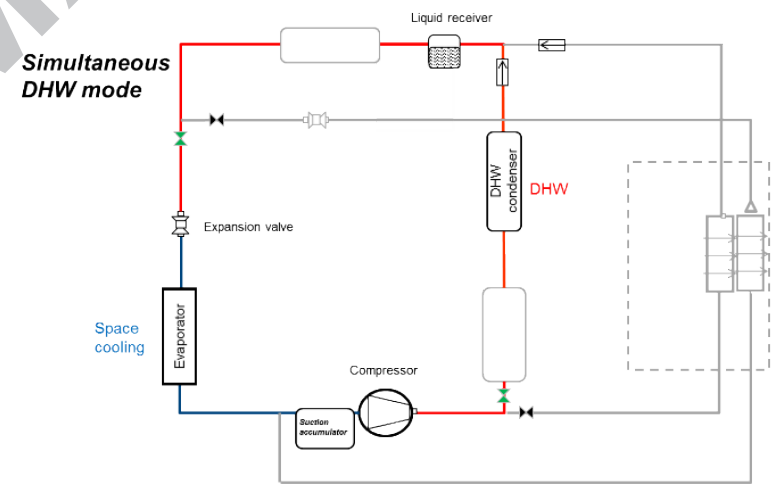

(b)

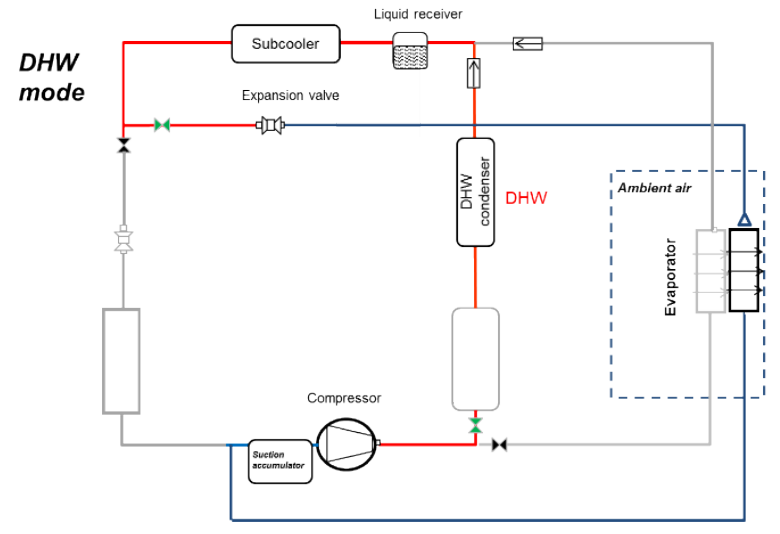

(d)

Figure 4: Operating modes of the R290 HPS prototype 


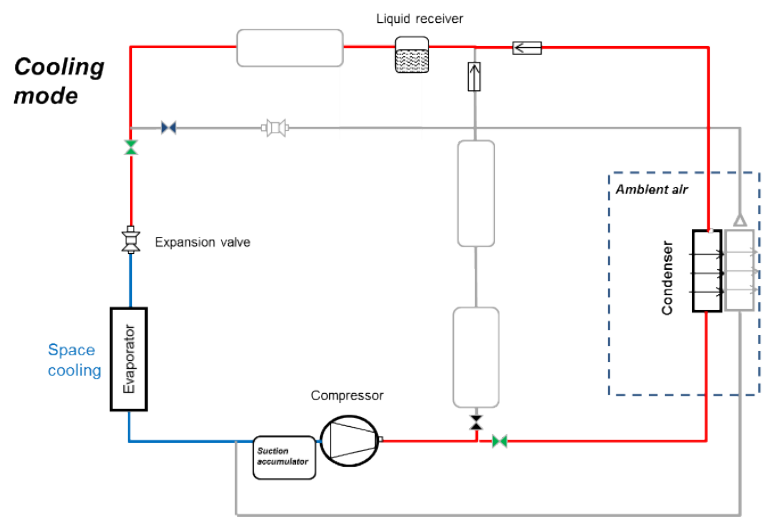

(e)

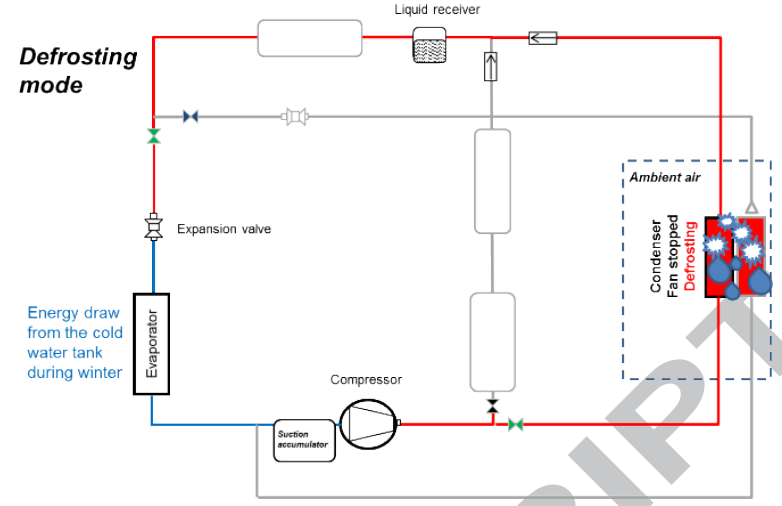

(f)

Figure 4: Operating modes of the R290 HPS prototype (continued)

\section{Experimental performance comparison}

\subsection{Global performance}

The performance of the two prototypes were evaluated following European Standard EN 14511 [44] in a climatic chamber. This standard imposes a steady state operation over a 30-minute duration with limited discrepancies of boundary conditions with respect to set values. The experimental temperature and pressure measurements at the inlet and the outlet of each component enabled to calculate energy and exergy rates involved for different operating conditions. The energy and exergy analysis is made in the common modes of both prototypes: simultaneous, heating and cooling modes. The DHW modes are not integrated to prototype P1 operation and the defrosting mode differs from the first prototype to the second. Therefore, these latter modes are excluded from the comparison.

The global performance is presented in Figure 5. These results include the consumptions of auxiliary fan and pumps. In general, prototype $\mathrm{P} 2$ shows better results than prototype P1. Indeed, the first prototype was developed more to observe the phenomenology occurring in such a multi-function heat pump in terms of fluid migration and heat pump behaviour during transitions than to reach a high performance. The design of P2 was mainly improved thanks to the lessons learned by the sizing mistakes made on P1. The compressor and the heat exchangers were better selected. The refrigerant choice has a relatively low impact on the performance. Propane generally has a 2 to $10 \%$ lower performance, depending on the operating conditions, compared to R407C [42]. In all cases, it can be noted that the difference between the exergy efficiencies of P1 and P2 decreases as the source temperatures get closer to the ambient temperature because the mechanical work recoverable through a Carnot cycle becomes lower. In the simultaneous mode, the ambient temperature of the climatic chamber is set at $11.3{ }^{\circ} \mathrm{C}$, which is the average annual temperature of the city of Rennes, France. The experimental COP improvement between P1 and P2 appears lower in the simultaneous mode than in the other modes. This observation is consistent with the simulation results presented in table 2 . 


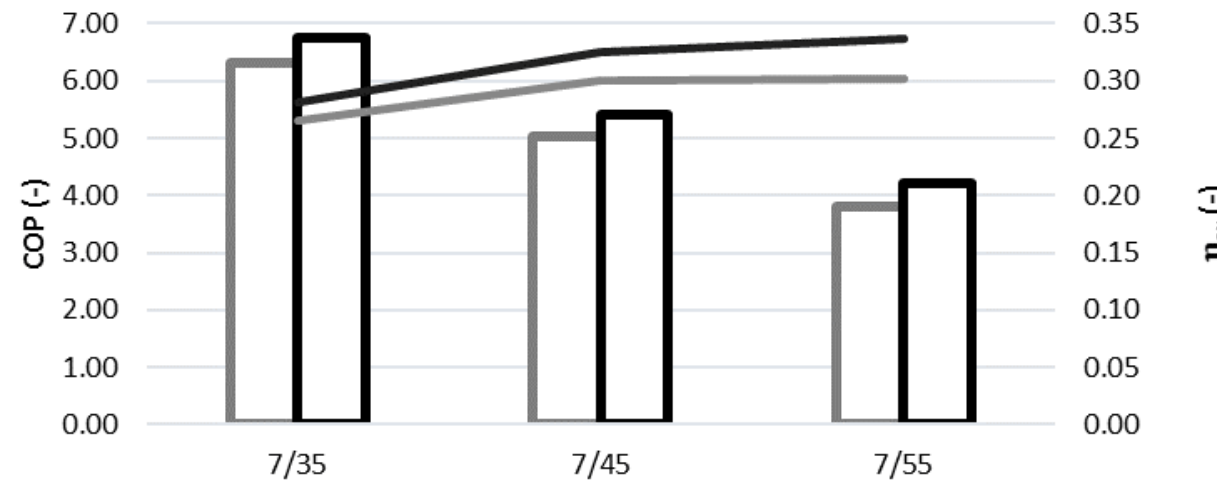

Temperature regime: cold water outlet / hot water outlet

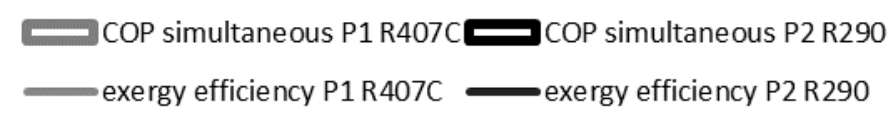

(a)

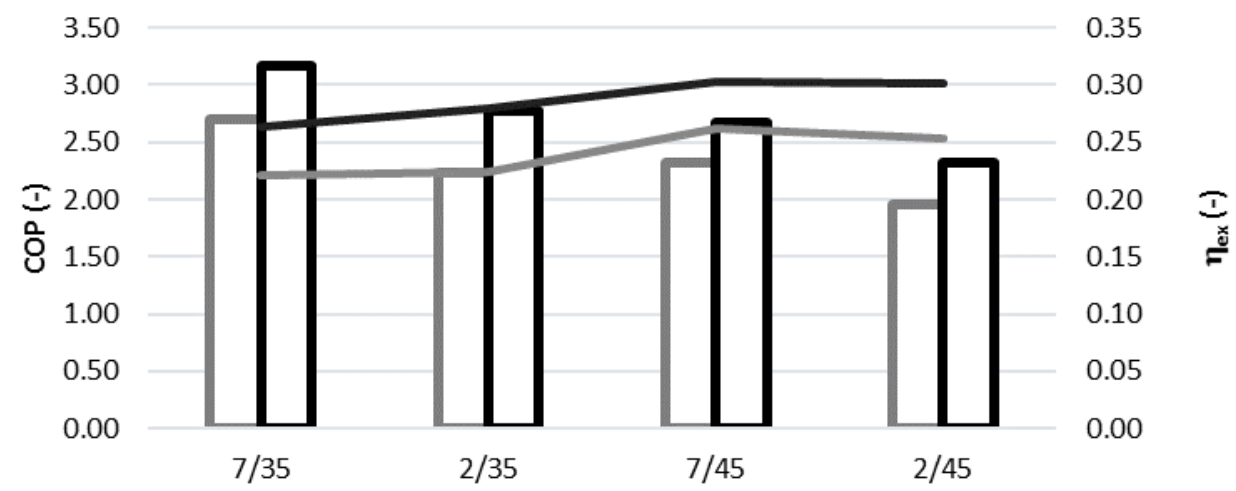

Temperature regime: ambient air inlet / hot water outlet

COP heating P1 R407C COP heating P2 R290

exergy efficiency P1 R407C — exergy efficiency P2 R290

(b)

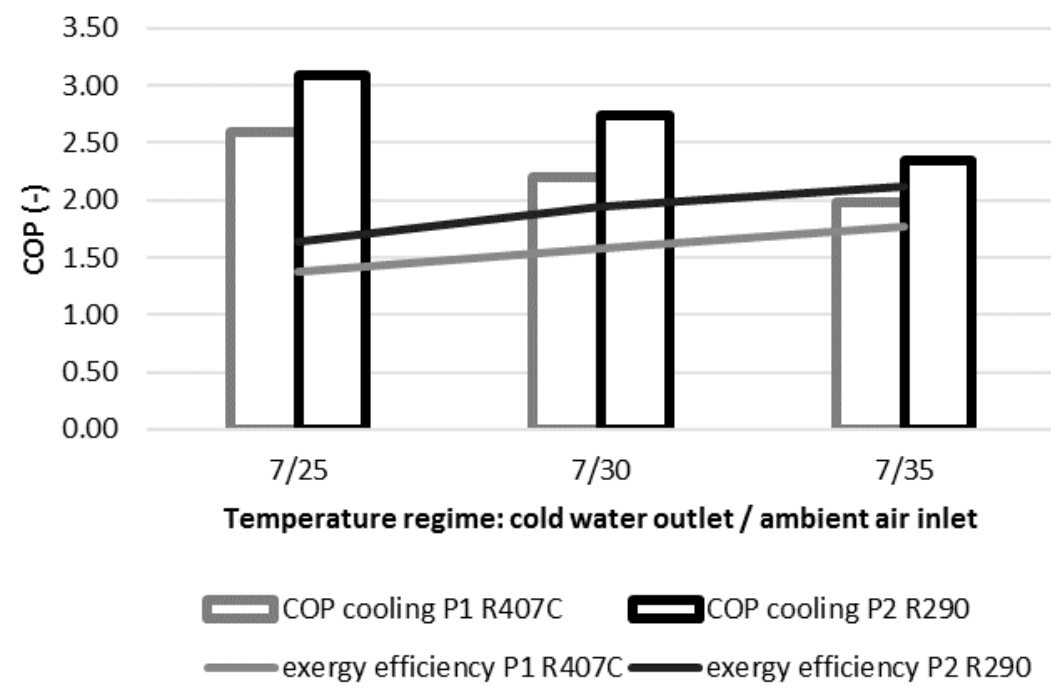

0.35

0.30

0.25

0.20

0.15

$\stackrel{5}{\stackrel{5}{g}}$

0.10

0.05

0.00

(c)

Figure 5: Performance of $P 1$ and $P 2$ prototypes in simultaneous mode (5a), heating mode (5b) and cooling mode (5c) 


\subsection{Exergy destruction per component}

For both prototypes, Table 3 details the destroyed exergy rates in each component of the refrigerating circuit in average values for every operating mode. The average was calculated for both prototypes tested in the same following operating conditions considering constant source temperatures: 7/25,7/35 and 7/45 in the simultaneous mode (constant outlet cold source / outlet hot source); 2/35, 7/35, 2/45 and 7/45 in the heating mode (constant inlet cold source / outlet hot source); $7 / 25,7 / 30$ and $7 / 35$ in the cooling mode (constant outlet cold source / inlet hot source). The heat exchangers are not the same in different modes; the condenser is the water condenser in the simultaneous and heating modes and the air heat exchanger in a cooling mode while the evaporator is the air heat exchanger in the heating mode and the water evaporator in the simultaneous and cooling modes. The numbers highlighted in a bold police correspond to high exergy destruction rates, over $1.5 \mathrm{~kW}$ for compressors and over $0.5 \mathrm{~kW}$ for heat exchangers to point out the maximum values.

These results first reveal a high exergy destruction in the compressor of P1 prototype in a heating mode. In the simultaneous mode, the higher exergy destruction rate is to be moderated by the fact that the total exergy destruction is also higher. Nevertheless, the compressor shows worse exergy performance for heating purposes. This result confirms that the main application of this P1 compressor, for which it was designed by the manufacturer, is cooling. The comparison of compressor maps showing the operating ranges of evaporating and condensing temperatures confirms this statement (Figure 6). The higher limit of condensing temperature of P1 compressor is lower than the one of P2. One operating point is even on the limit whereas for $\mathrm{P} 2$, all points are in the operating range.

Figure 7 compares the total exergy destruction of the two prototypes in the three modes divided by the thermal energy produced in order to have an equivalent base of heat and cold production. The simultaneous mode presents clearly the lowest exergy destruction ratios. Prototype P2 shows better performance, especially in the cooling mode.

Figures 8 to 11 present the exergy destruction ratio in the compressor, the evaporator, the condenser and the expansion valve respectively. This ratio is defined by the exergy destruction in the component divided by the total exergy destruction. P2 compressor shows an even ratio confirming that the compressor was better selected. Secondly, exergy destruction analysis exposes an under-sizing of heat exchangers that can be observed in some operating modes. The exergy destruction ratio of condensers and evaporators is shown in figure 9 and 10. P1 air condenser and water evaporator in the cooling mode and P2 air evaporator in the heating mode seem under-sized. In the case of P2, a high refrigerant pressure drop in the distributor and the air evaporator was assessed at $2.1 \pm 0.6$ bar using the pressure measurement at the inlet and the evaluated evaporating pressure. Therefore, part of the exergy destruction ratio would be attributed to the expansion valve if the distributor tubes had less pressure drops. This fact can explain the very low exergy destruction in the expansion valve in the heating mode in figure 11. 
Table 3: Destroyed exergy rates in different components for the three operating modes and the two prototypes

\begin{tabular}{|c|c|c|c|c|c|c|}
\hline \multirow{2}{*}{ Component } & \multicolumn{2}{|c|}{ Simultaneous mode } & \multicolumn{2}{c|}{ Heating mode } & \multicolumn{2}{c|}{ Cooling mode } \\
\cline { 2 - 7 } & P1 R407C & P2 R290 & P1 R407C & P2 R290 & P1 R407C & P2 R290 \\
\hline Compressor $(\mathrm{kW})$ & $\mathbf{1 . 5 9}$ & 1.38 & $\mathbf{1 . 6 2}$ & 1.34 & 1.24 & $\mathbf{1 . 5 3}$ \\
\hline Condenser $(\mathrm{kW})$ & 0.44 & 0.32 & 0.27 & 0.28 & $\mathbf{0 . 5 9}$ & 0.42 \\
\hline Expansion valve $(\mathrm{kW})$ & 0.43 & 0.37 & 0.18 & 0.10 & 0.44 & 0.33 \\
\hline Evaporator $(\mathrm{kW})$ & 0.46 & $\mathbf{0 . 5 4}$ & 0.33 & $\mathbf{0 . 6 2}$ & $\mathbf{0 . 7 5}$ & $\mathbf{0 . 5 7}$ \\
\hline Total $(\mathbf{k W})$ & $\mathbf{2 . 9 1}$ & $\mathbf{2 . 6 1}$ & $\mathbf{2 . 4 1}$ & $\mathbf{2 . 3 9}$ & $\mathbf{3 . 0 2}$ & $\mathbf{2 . 8 6}$ \\
\hline
\end{tabular}

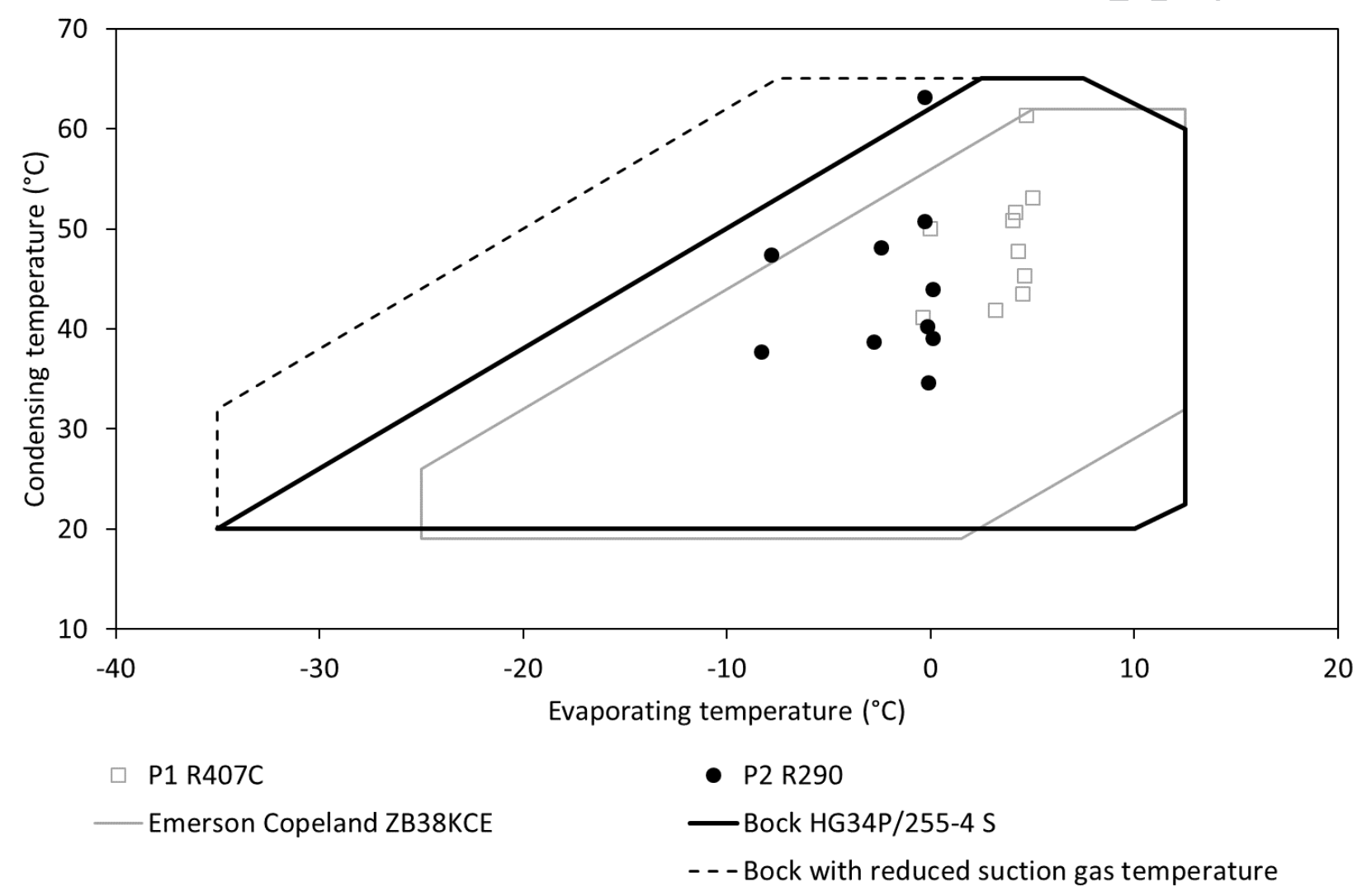

Figure 6. Operating limits and operating points of P1 and P2 compressors

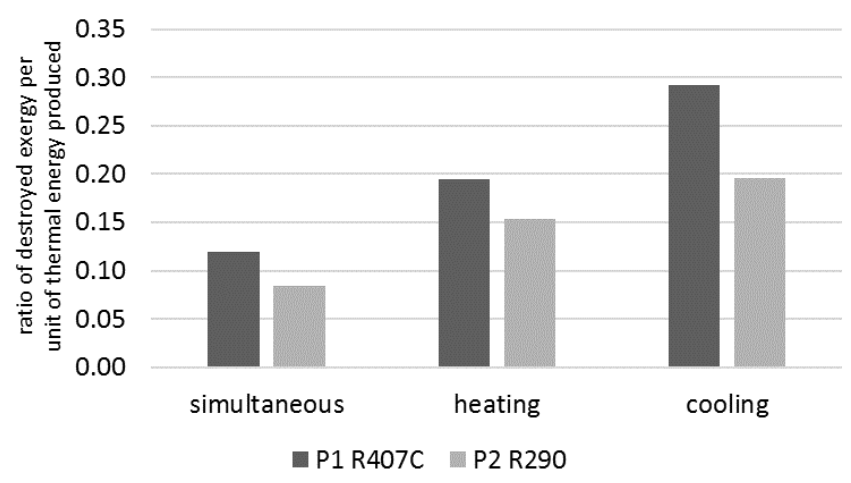

Figure 7. Ratios of total destroyed exergy per unit of thermal energy produced 


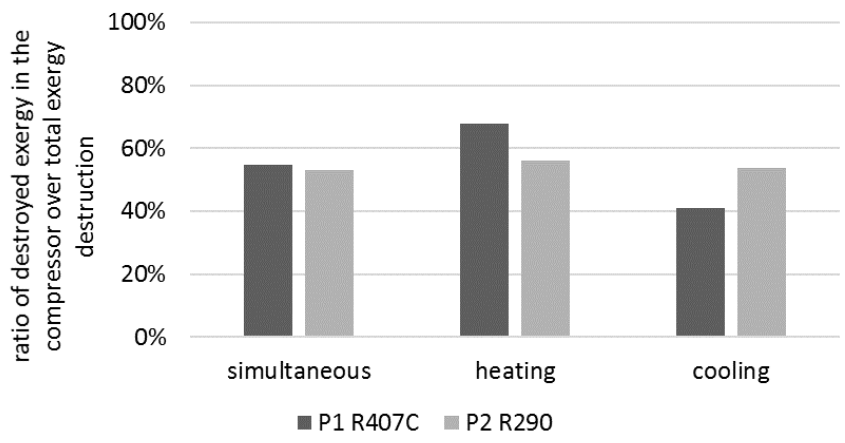

Figure 8. Exergy destruction ratios in the compressors

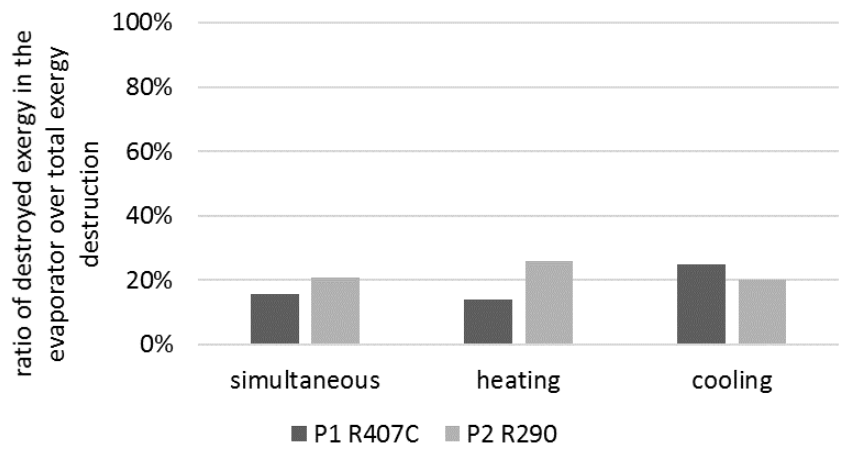

Figure 9. Exergy destruction ratios in the evaporators

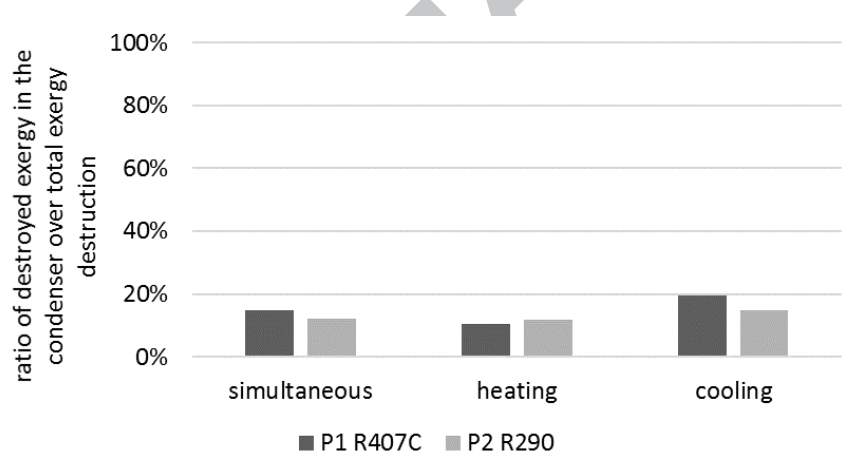

Figure 10. Exergy destruction ratios in the condensers

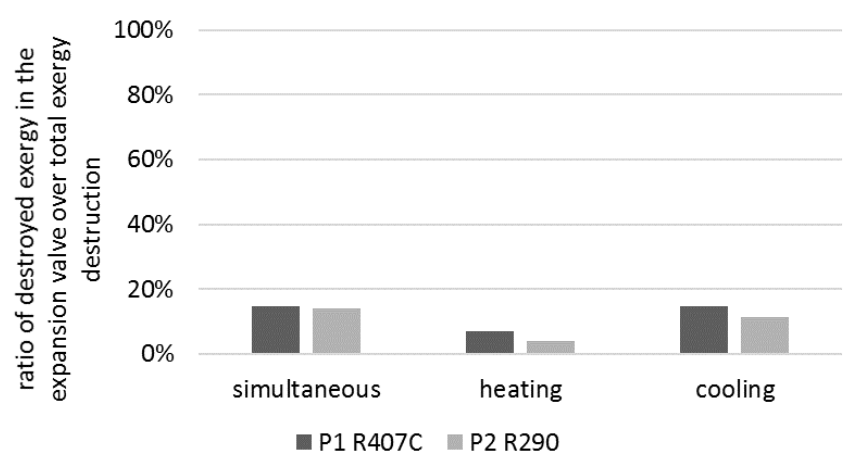

Figure 11. Exergy destruction ratios in the expansion valves

\section{Conclusion}

The HPS enables electric energy saving by the operation of the simultaneous production of heating and cooling energies. Heat pumps for simultaneous heating and cooling appear as interesting solutions for new office and residential 
buildings with a specific mode for DHW production. Two prototypes were built and tested under very similar operating conditions defined by European Standard EN14511. The first one, using R407C as a refrigerant, is a demonstrator intended to show phenomena in the fields of heat transfer and fluid dynamics. The second one is a near-industrial welldesigned prototype that ended in a patent deposit [49].

An exergy analysis was conducted to study the evolution between the first and the second prototypes. The comparison of global energy and exergy performance factors show that improvements were actually made. The exergy destruction occurs mainly in the compressors, where the heat losses are high. The performance of prototype P1 is reduced by an under-sized water evaporator. The impact of the choice of the refrigerant is considered as relatively low. Prototype P2 presents much lower exergy destruction ratios thanks to a better design of the components. In this study, the exergy analysis proves its benefits for a better design of systems in terms of energy use. It enables to identify components having higher exergy destruction, to correct sizing problems. High exergy destructions can be attributed to high pressure drops or high temperature differences in heat exchangers leading to higher thermal losses and less efficient thermodynamic cycles.

The present article applies the exergy analysis to a very specific type of multi-function heat pump. The results compare three operating modes (heating, cooling and simultaneously heating and cooling) for the same machine that uses the same compressor and for two different heat pumps of similar power. The comparison of operating modes in terms of exergy destruction enables to detect the suitability of a component to the different modes, especially for the compressor. The impact of changing the refrigerant is also addressed through complementary simulations. The effect of the temperature glide of the zeotropic mixture of R407C is beneficial for the simultaneous mode.

Unfortunately, the exergy analysis was realized after having constructed the two prototypes. The improvement between prototypes $\mathrm{P} 1$ and $\mathrm{P} 2$ was made regarding energy analysis only resulting in a finer dimensioning. The exergy analysis should now be completed for dimensioning more precisely a commercial heat pump system. The compressor should be chosen so that the operating conditions of standard EN14511 represented in a compressor map give points well inside the operating zone. Indeed, a compressor is a like high pressure pump having a maximum efficiency in the middle of its operating range. Simulations should be made beforehand to size the heat exchangers and to obtain the evaporating and condensing temperatures depending on the temperatures of the heat source and the heat sink. This step has to be carried out in the aim of reducing exergy destruction. On the one hand, the exergy destruction will be minimized with the maximum heat transfer surface area. On the other hand, the price is linked to the mass of matter. Therefore, to stay in the same objective, an exergo-economic study should be used to minimize the cost of the investments and of the exergy flows in the heat exchangers. 
In the process of designing new machines, the exergy assessment helps improve the components most impacted by exergy destruction until achieving acceptably low values. This study demonstrates that an exergy analysis applied to every prototype tested in the process is a valuable tool.

\section{Acknowledgements}

This study is the result of the collaboration between the Technical Centre for refrigeration and HVAC, Pôle Cristal in Dinan, where the experimental tests were realized, and LGCGM laboratory of Universite de Rennes with the support of the European Union and the French ANRT.

\section{References}

[1] I. Dincer and Y. A. Cengel, "Energy, entropy and exergy concepts and their roles in thermal engineering," Entropy, vol. 3, no. 3, pp. 116-149, 2001.

[2] H. Torío, A. Angelotti, and D. Schmidt, "Exergy analysis of renewable energy-based climatisation systems for buildings: A critical view," Energy Build., vol. 41, no. 3, pp. 248-271, 2009.

[3] J. U. Ahamed, R. Saidur, and H. H. Masjuki, “A review on exergy analysis of vapor compression refrigeration system,” Renew. Sustain. Energy Rev., vol. 15, no. 3, pp. 1593-1600, 2011.

[4] “EES , Engineering Equation Solver. F-Chart Software. http://www.fchart.com/[accessed: June 2016].” .

[5] T. Morosuk and G. Tsatsaronis, "Advanced exergetic evaluation of refrigeration machines using different working fluids," Energy, vol. 34, no. 12, pp. 2248-2258, 2009.

[6] U. Çakir and K. Çomakli, "Exergetic interrelation between an heat pump and components," Appl. Therm. Eng., vol. 105, pp. 659-668, 2015.

[7] F. Fazelpour and T. Morosuk, "Exergoeconomic analysis of carbon dioxide transcritical refrigeration machines,” Int. J. Refrig., vol. 38, no. 1, pp. 128-139, 2014.

[8] O. Joneydi Shariatzadeh, S. S. Abolhassani, M. Rahmani, and M. Ziaee Nejad, “Comparison of transcritical $\mathrm{CO} 2$ refrigeration cycle with expander and throttling valve including/excluding internal heat exchanger: Exergy and energy points of view," Appl. Therm. Eng., vol. 93, pp. 779-787, 2016.

[9] R. Baccoli, C. Mastino, and G. Rodriguez, "Energy and exergy analysis of a geothermal heat pump air conditioning system," Appl. Therm. Eng., vol. 86, pp. 333-347, 2015.

[10] M. R. Ally, J. D. Munk, V. D. Baxter, and A. C. Gehl, "Exergy and energy analysis of a ground-source heat 
pump for domestic water heating under simulated occupancy conditions," Int. J. Refrig., vol. 36, no. 5, pp. 1417-1430, 2013.

[11] EU Comission, “Technology Roadmap,” 2010.

[12] R. Ghoubali, P. Byrne, J. Miriel, and F. Bazantay, "Simulation study of a heat pump for simultaneous heating and cooling coupled to buildings," Energy Build., vol. 72, pp. 141-149, 2014.

[13] E. Lecrivain, G. Laroche, and A. Vallot, "La production simultanée d'eau glacée et d'eau chaude à $95^{\circ} \mathrm{C}$ par une thermofrigopompe d'une laiterie," Int. J. Refrig., vol. 5, no. 4, pp. 221-225, 1982.

[14] V. S. Ghosh, S., Devotta, S., Patwardhan, "The economics of heat pump systems for simultaneous heating and cooling," Heat Recover. Syst., vol. 7, no. 2, pp. 159-166, 1987.

[15] G. Gong, W. Zeng, L. Wang, and C. Wu, "A new heat recovery technique for air-conditioning/heat-pump system," Appl. Therm. Eng., vol. 28, no. 17-18, pp. 2360-2370, 2008.

[16] M. Fatouh and E. Elgendy, "Experimental investigation of a vapor compression heat pump used for cooling and heating applications," Energy, vol. 36, no. 5, pp. 2788-2795, 2011.

[17] J. Sarkar, S. Bhattacharyya, and M. R. Gopal, "Optimization of a transcritical CO2 heat pump cycle for simultaneous cooling and heating applications,” Int. J. Refrig., vol. 27, no. 8, pp. 830-838, Dec. 2004.

[18] J. Sarkar, S. Bhattacharyya, and M. R. Gopal, "Simulation of a transcritical CO2 heat pump cycle for simultaneous cooling and heating applications," Int. J. Refrig., vol. 29, no. 5, pp. 735-743, 2006.

[19] P. Le Goff, "Exergetic, economic or ecologic optimisations of heat-cold-pumps," Entropie, vol. 220/221, pp. 6$11,1999$.

[20] N. Agrawal and S. Bhattacharyya, “Optimized transcritical CO2 heat pumps: Performance comparison of capillary tubes against expansion valves," Int. J. Refrig., vol. 31, no. 3, pp. 388-395, 2008.

[21] N. Agrawal and S. Bhattacharyya, "Experimental investigations on adiabatic capillary tube in a transcritical CO2 heat pump system for simultaneous water cooling and heating,” Int. J. Refrig., vol. 34, no. 2, pp. 476-483, 2011.

[22] P. Byrne, J. Miriel, and Y. Lenat, "Experimental study of an air-source heat pump for simultaneous heating and cooling - Part 1: Basic concepts and performance verification," Appl. Energy, vol. 88, no. 5, pp. 1841-1847, 2011.

[23] P. Byrne, J. Miriel, and Y. Lenat, "Experimental study of an air-source heat pump for simultaneous heating and cooling - Part 2: Dynamic behaviour and two-phase thermosiphon defrosting technique," Appl. Energy, vol. 88, 
no. 9, pp. 3072-3078, 2011.

[24] J. Stene, "Residential CO2 heat pump system for combined space heating and hot water heating," Int. J. Refrig., vol. 28 , no. 8 , pp. 1259-1265, 2005.

[25] P. Bouttefroy, “Thermofrigopompe chez IBM Corbeil,” Rev. Générale du Froid, vol. 6, pp. 19-23, 1990.

[26] C. Naveteur, J., Bruss, "Chauffage et Rafraîchissement de la CAF de Lyon : une Réussite Exemplaire !,” Rev. Générale du Froid du Cond. d'air, vol. 1079, pp. 23-26, 2007.

[27] S. White, D. Cleland, and S. Cotter, “A heat pump for simultaneous refrigeration and water heating," IPENZ Trans., vol. 24, no. 1, pp. 36-43, 1997.

[28] K. J. Chua, S. K. Chou, and W. M. Yang, “Advances in heat pump systems: A review,” Appl. Energy, vol. 87, no. 12 , pp. 3611-3624, 2010.

[29] T. Nagota, Y. Shimoda, and M. Mizuno, "Verification of the energy-saving effect of the district heating and cooling system-Simulation of an electric-driven heat pump system,” Energy Build., vol. 40, no. 5, pp. 732-741, 2008 .

[30] L. Zhen, D. M. Lin, H. W. Shu, S. Jiang, and Y. X. Zhu, "District cooling and heating with seawater as heat source and sink in Dalian, China," Renew. Energy, vol. 32, no. 15, pp. 2603-2616, 2007.

[31] Z. M. Amin and M. N. A. Hawlader, "Analysis of solar desalination system using heat pump," Renew. Energy, vol. 74, pp. 116-123, 2015

[32] A. A. A. Attia, "New proposed system for freeze water desalination using auto reversed R-22 vapor compression heat pump," Desalination, vol. 254, no. 1-3, pp. 179-184, 2010.

[33] P. Byrne, J. Miriel, and Y. Lenat, "Design and simulation of a heat pump for simultaneous heating and cooling using HFC or CO2 as a working fluid,” Int. J. Refrig., vol. 32, no. 7, pp. 1711-1723, 2009.

[34] P. Byrne, J. Miriel, and Y. Lénat, "Modelling and simulation of a heat pump for simultaneous heating and cooling," Build. Simul., vol. 5, no. 3, pp. 219-232, 2012.

[35] H. Kang, Y. Joo, H. Chung, Y. Kim, and J. Choi, "Experimental study on the performance of a simultaneous heating and cooling multi-heat pump with the variation of operation mode," Int. J. Refrig., vol. 32, no. 6, pp. 1452-1459, 2009.

[36] Y. Joo, H. Kang, J. H. Ahn, M. Lee, and Y. Kim, "Performance characteristics of a simultaneous cooling and heating multi-heat pump at partial load conditions," Int. J. Refrig., vol. 34, no. 4, pp. 893-901, 2011.

[37] H. W. Jung, H. Kang, H. Chung, J. H. Ahn, and Y. Kim, "Performance optimization of a cascade multi- 
functional heat pump in various operation modes," Int. J. Refrig., vol. 42, pp. 57-68, 2014.

[38] X. Liu, S. K. Lau, and H. Li, “Optimization and analysis of a multi-functional heat pump system with air source and gray water source in heating mode," Energy Build., vol. 69, pp. 1-13, 2014.

[39] European Commission, "REGULATION (EU) No 517/2014 OF THE EUROPEAN PARLIAMENT AND OF THE COUNCIL of 16 April 2014 on fluorinated greenhouse gases and repealing Regulation (EC) No 842/2006," Off. J. Eur. Union, pp. 150-195, 2014.

[40] D. Coulomb, “Cancun après Copenhague,” Rev. Général du Froid, vol. 1110, pp. 25-27, 2011

[41] R. Ghoubali, P. Byrne, and F. Bazantay, "Refrigerant charge optimisation for propane heat pump water heaters," Int. J. Refrig., vol. 76, 2017.

[42] P. Byrne, Advances in air-source heat pump water heaters. 2013.

[43] “Coolpack.” Denmark Technical University, Department of Mechanical Engineering.

[44] European Commission, "EN 14511: Air conditioners, liquid chilling packages and heat pumps with electrically driven compressors for space heating and cooling," 2013

[45] L. Rajapaksha and K. O. Suen, "Influence of reversing methods on the performance of a reversible water-towater heat pump," Appl. Therm. Eng., vol. 23, no. 1, pp. 49-64, 2003.

[46] L. Rajapaksha and K. O. Suen, "Influence of liquid receiver on the performance of reversible heat pumps using refrigerant mixtures," Int. J. Refrig., vol. 27, no. 1, pp. 53-62, 2004.

[47] P. Byrne, L. Serres, R. Ghoubali, and J. Miriel, "Experimental Study and Simulation of a Thermosiphon Defrosting Technique for Air-Source Heat Pumps,” ASHRAE Trans., vol. 119, 2013.

[48] R. Ghoubali, P. Byrne, and F. Bazantay, "Etude expérimentale d'une thermofrigopompe au propane en fonctionnement hivernal," in IREEC1: Refrigeration Energy and Environment, Hammamet, 2016, 2016.

[49] R. Ghoubali, F. Bazantay, L. Mear, J. Miriel, and P. Byrne, "Refrigerating circuit, facility comprising such a circuit and corresponding method," WO 2015/015104 A1, 2015.

\section{Nomenclature}

Latin letters:
ATEX atmosphères explosives
COP coefficient of performance
DHW domestic hot water 


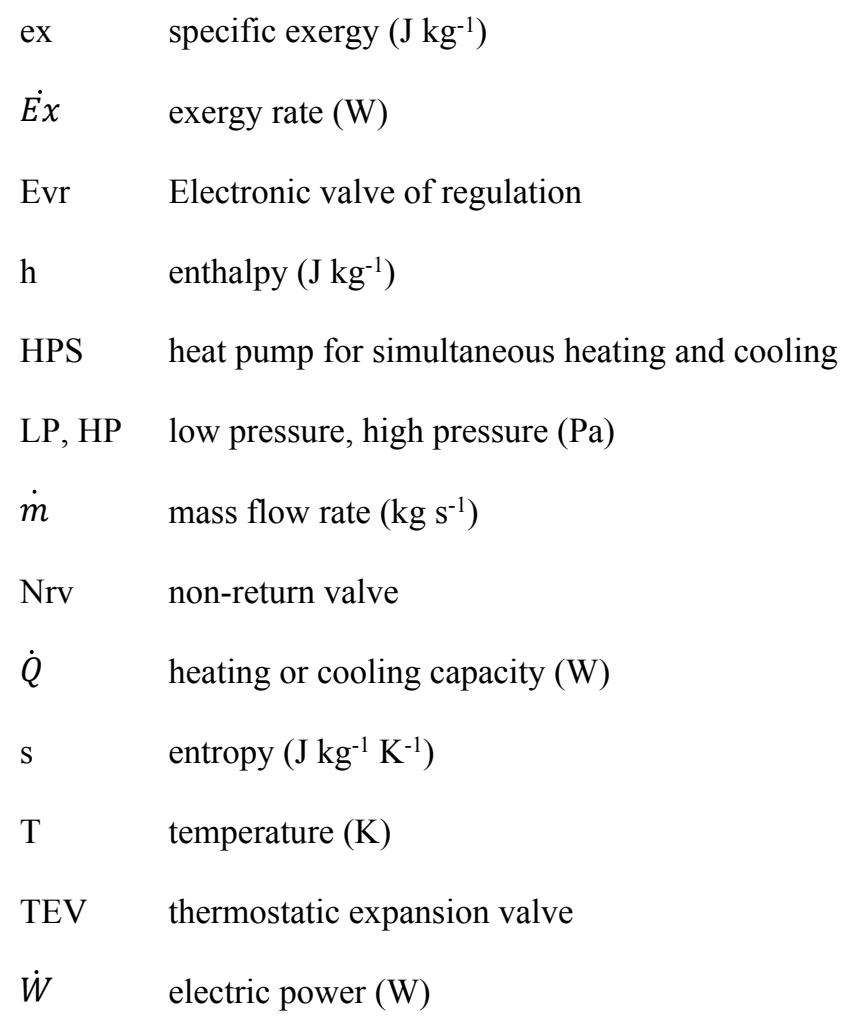




\section{Highlights}

- Two prototypes of heat pump for simultaneous heating and cooling were built and tested

- An exergy analysis was performed to assess the operation of each component

- Design problems were detected and improvements were made between $1^{\text {st }}$ and $2^{\text {nd }}$ prototypes

- Exergy destruction should be low and balanced between components 